\title{
Lactose versus Lactose Free Regimen in Children with Acute Diarrhea
}

\author{
Sinan Abdulrazzaq ${ }^{1 *(1 D}$, Faten Alaa Jaafar ${ }^{2}$, Zahoor Abdulmohsin Mohammed $^{3}$ \\ ${ }^{1}$ Department of Pediatrics, College of Medicine, Al-Nahrain University, Baghdad, Iraq; ${ }^{2}$ Central Teaching Hospital of Pediatrics, \\ Baghdad, Iraq; ${ }^{3}$ Al-Immamian Al-Kadymian Medical City, Baghdad, Iraq
}

Abstract

Edited by: Ksenija Bogoeva-Kostovska Citation: Abdulrazzaq Lactose versus. Lactose Free Regimen in Children with Acute Diarrhea. Open Access Maced J Med Sci. 2021 Oct 19;9(B):1279-1282.https://doi.org/10.3889/oamjms.2021.6733 Keywords: Acute diarrhea; Lactose free; Childre Correspondence: Dr. Sinan Abdulrazzaq, College edicine, Al-Nahrain University, Baghdad, Iraq Rzaq1980@gmail.com Received: 27-Jun-2021 Revised: 05-Aug-2021 Copyright: $\odot 2021$ Sinan Abdulrazzaq, Faten Alaa Jaafar Funding: This research did not receive any financial Competing Interests: The authors have declared that no competing interests exis Open Access: This is an open-access article distribute under the terms of the Creative Commons Attribution-

\begin{abstract}
BACKGROUND: Acute diarrhea (AD) is the most frequent gastroenterological disorder, and the main cause of dehydration in childhood, and it is one of the most important causes of morbidity and mortality in children.

AIM: Assessment of lactose-free formula effect in nutritional treatment in formula-fed children with acute diarrhea.

PATIENTS AND METHODS: A cross-section interventional study carried out on 60 formula-fed children, under two years, referring with acute diarrhea, 30 children obtain lactose-free formulation and 30 children with no lactosecontaining formula. According to the period of diarrheal stop and weight, changes compering two groups.

RESULTS: Thirty-two males and 28 females children ( $7.25 \pm 5.1$ months) included. Children with lactose-free formula had a significantly slighter dated to diarrhea relief compared with control group children $(p<0.01)$. No variance between two groups in weight change $(6.9 \pm 3.03$ vs. $7.05 \pm 3.07 \mathrm{~kg}, p=0.2)$. (46.6\%) of patients on Lactose free formula were discharged on the third post admission day, lactose-free formula has more effective recovery to those on cow milk formula ( $4.1 \pm 1.2$ vs. $6 \pm 1.3$ days, $p<0.01$ significant)

CONCLUSION: Quick giving of lactose-free formulation to children on formula feeding show rapid relief of acute diarrhea.
\end{abstract}

\section{Introduction}

Worldwide diarrheal diseases are responsible for a significant proportion of morbidity in children under 2 years of age and remain as a leading cause childhood death [1]. The global mortality may be declining but the overall incidence of diarrhea declined from 3.4 to 2.9 episodes per child-year in the past 2 decades [2]. This decline is a result of preventive Rotavirus vaccine; improve case of management of diarrhea, improved nutrition of the infants and children, and the use of home and hospital oral rehydration therapy [3]. Diarrheal illness, especially early and repeated episodes among young children can be associated with malnutrition, micronutrient deficiency, and a significant deficit in psychomotor and cognitive development [4]. Gastroenteritis occurs through infection come from feco oral way, by consumption of the dirty food or water [5]. The pathogenesis and harshness of the illness depend on the microorganisms yield toxin or not or invasive and multiply inside food. Rotavirus has multiple infectious agents which goal the microvilli tips of the enterocytes and go inside cell by direct invasive resulting in villus shortening and loss of enterocytes and loss absorptive surface [6]. The risk of gastroenteritis is higher in malnourished children with zinc and Vitamin A deficiency [7]. Most of the clinical signs of diarrhea determine according to the infecting pathogen, dose of inoculum, and the development of complications [8]. Most of the complications relate to the delay of treatment without early use of oral rehydration therapy, patient may develop dehydration and its complications [9]. In developing countries, bacteremia is a recognized complication in malnourished children with diarrhea. The suitable managing of acute diarrhea is fluid and electrolytes disturbance improvement, appropriate antibiotics, sufficient nutritional maintenance which is chiefly significant in developing countries where a significant association between diarrhea and growth of children [10]. Therefore, when rehydration is finished food restored while oral rehydration treatment is stay to replace any loss from vomiting or stool [11]. The use of zinc supplements in developing countries leads to reduce duration and severity of diarrhea and decrease mortality and hospital admission [12]. In addition, the use of antibiotics in selected cases of bacterial diarrhea reduces the duration and severity. Lactose intolerance can occur among infants and young children with acute diarrheal disease due to deficiency of lactase enzyme, resulting in bloating, diarrhea, abdominal pain, and distention [13]. The importance of lactose in growth and development is often unrecognized so the use of low lactose diet in-patient with diarrhea may be one of the methods for balance between the benefit and adverse effects of lactose [14]. Still, there is debate in the use 
of lactose-free formula and usual use for children with acute diarrhea [15]. The aim of study assessment of lactose-free formula effect in nutritional treatment in formula-fed children with acute diarrhea.

\section{Methods}

A cross-section interventional study carried out on 60 formula-fed children under 2 years who's admitted to the pediatric ward in AI-IMMAMIAN AL-KADYMIAN MEDICAL CITY, BAGHDAD, IRAQ with acute diarrhea from $1^{\text {st }}$ of October 2019 to $1^{\text {st }}$ February 2020. The data of the study was collected that include: sociodemographic characteristics of children which include age, sex, residence, weight, type of feeding, number of bowel motion, stool consistency, date of admission, state of dehydration according to clinical bases, and days of hospitalization. Children who are included in the study: healthy before the attack of acute diarrhea and not suffering from a chronic illness or severely malnourished child. The sample was divided into two groups: $1^{\text {st }}$ group which consists of $(30)$ children on Lactose-free formula, $2^{\text {nd }}$ group which consists (30) children on cow milk formula. At admission, take the demographic data and medical history then dehydration evaluated and give oral rehydration solution according to the World Health Organization (WHO) recommendation. Investigation done; blood test and stool culture. After that maintenance treatment done, children alternately owed to obtain either lactose-free or lactose-containing formula. The body weight, Hydration status, stool frequency, consistency, and duration were recorded daily until the children discharged, Diarrheal duration was defined from the time of admission to the time of the first formed stool if followed by two consecutive non watery stools or by 12 hours without further evacuations. The consent was got from all parents after complete description of the study goal and procedure. Statistical analysis done by using SPSS 13 pack for windows (version 16.0) and Chi-square test used for comparing groups. In addition, Microsoft excel 2010 for table layout. The level of signification was (0.05) for comparison, descriptive, and analytic statistics carried out.

\section{Results}

The result of this research showed that from (60) children aged under two years who were involved in this research there were 30 children $(50 \%)$ on cowmilk formula and 30 children $(50 \%)$ were on lactosefree milk. Analysis of the residency revealed that
$43(71 \%)$ of children are from rural area (22 male $52 \%$ and 21 female $48 \%)$, Patients from urban is $17(29 \%)$ (10 male 59\% and 7 female 41\%) as shown in Figure 1.

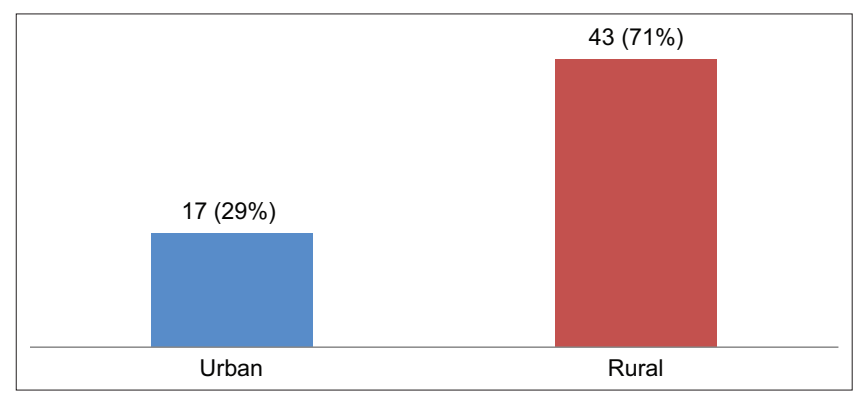

Figure 1: The percentage of residency among the cases

After treatment, children received lactose-free formula had a significantly further fast diarrheal release compared with children had cow milk formula (2.9 \pm 0.9 vs. $4.3 \pm 0.8)$ as shown in Table $1, p$-value (0.008) and its significant.

Table 1: Duration of improvement in both groups

\begin{tabular}{|c|c|c|c|c|c|c|}
\hline \multirow[t]{2}{*}{ Days of diarrheal relief } & \multicolumn{2}{|c|}{ Lactose free formula } & \multicolumn{2}{|c|}{ Cow milk formula } & \multicolumn{2}{|c|}{ Total } \\
\hline & $\mathrm{n}$ & $\%$ & $\mathrm{n}$ & $\%$ & $\mathrm{n}$ & $\%$ \\
\hline$\leq 3$ & 22 & 36.5 & 5 & 8.5 & 27 & 45 \\
\hline$>3$ & 8 & 13.5 & 25 & 41.5 & 46 & 55 \\
\hline Total & 30 & 50 & 30 & 50 & 60 & 100 \\
\hline
\end{tabular}

Weight significantly increased in both groups, mean weight for children on cow milk formula (6.9 \pm 3.03 to $7.05 \pm 3.07 \mathrm{~kg}$ ), And the mean weight for lactose-free formula $(7.6 \pm 2.3$ to $7.7 \pm 2.2 \mathrm{~kg})$, but there was no difference between in weight change as shown in Figure 2, The $p$-value is $(0.2)$ which is not significant.

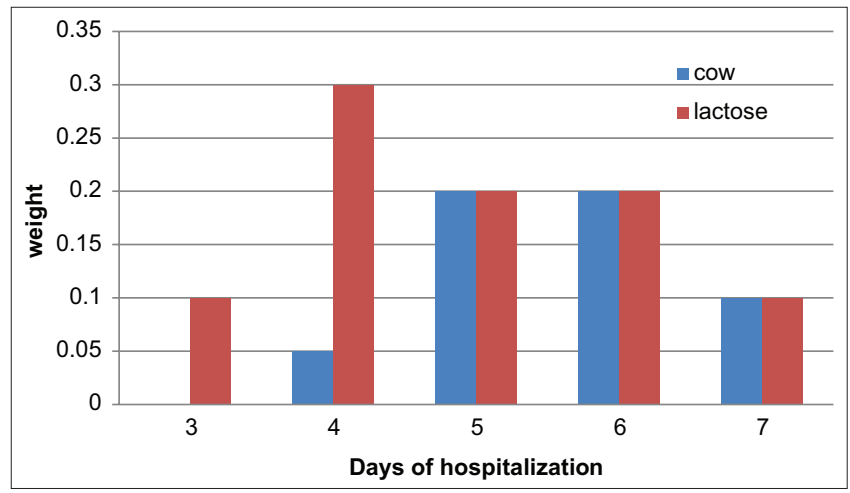

Figure 2: Weight gain in both groups

Concerning the effect of feeding types on duration of hospitalization. The results showed that from 30 children on lactose-free formula, there are $14(23.3 \%)$ discharged after 3 days, 5 children $(8.3 \%)$ discharged after 4 days and (6) children (10\%) discharged after 5 days, 4 children (7\%) after 6 days while the other remaining child discharged after more than 6 days. From (30) children on cow-milk formula, there is no one discharged in the first 3 days, 4 children (7\%) discharged after 4 days, 7 children (11.6\%) discharged after 5 days, 7 children (11.6\%) after 6 days while the remaining children discharged after more than 6 days, so the mean duration hospital days for 
lactose-free formula is $(4.1 \pm 1.2)$, male $(4.2 \pm 1.3)$ female $(3.9 \pm 1.1)$. In addition, for cow milk formula is $(6 \pm 1.3)$, male $(5.8 \pm 1)$ female $(6.1 \pm 1.6)$, as shown in Table 2, p-value $(<0.01)$ which is significant.

Table 2: Duration of hospitalization in both groups

\begin{tabular}{|c|c|c|c|c|c|c|}
\hline \multirow[t]{3}{*}{ Days of hospitalization } & \multicolumn{6}{|c|}{ Feeding types } \\
\hline & \multicolumn{2}{|c|}{$\begin{array}{l}\text { Lactose free } \\
\text { formula }\end{array}$} & \multicolumn{2}{|c|}{$\begin{array}{l}\text { Cow milk } \\
\text { formula }\end{array}$} & \multicolumn{2}{|c|}{ Total } \\
\hline & $\mathrm{n}$ & $\%$ & $n$ & $\%$ & $n$ & $\%$ \\
\hline 3 & 14 & 23.30 & 0 & 0 & 14 & 23.30 \\
\hline 4 & 5 & 8.30 & 4 & 7 & 9 & 15.30 \\
\hline 5 & 6 & 10 & 7 & 11.60 & 13 & 21.60 \\
\hline 6 & 4 & 7 & 7 & 11.60 & 11 & 18.60 \\
\hline$>6$ & 1 & 1.60 & 12 & 20 & 13 & 21.60 \\
\hline Total & 30 & 50 & 30 & 50 & 60 & 100 \\
\hline
\end{tabular}

\section{Discussion}

Current study aims to assess the efficiency of quick giving of lactose-free formulation to children on formula feeding show rapid relief of acute diarrhea, the entire number of patients is 60 , under 2 years of age, $50 \%$ of them on lactose-free formula and $50 \%$ on lactose-containing formula, most of them from rural areas $71 \%$, while $29 \%$ from urban areas. There is a significant decrease in the time of diarrhea in children who give lactose-free formulation compared with children on lactose-encompassing formula, $p$-value $<0.01$ significant. Studies done by Hossien saneian et al. also showed rapid diarrheal relief in-patient on lactose-free formula, which support our study [16]. Xu et al. also found shorter period of diarrhea remission in lactose free formula, which also support our study [17]. A study by Simakachorn et al. also found a significant shorter duration of diarrhea by $20.5 \mathrm{~h}$ in-patient on lactose-free formula [18]. In opposite to studies representative the advantage of lactose-free formula, Brown $\mathrm{KH}$ and colleagues study concluded that most patients with diarrhea can be successfully managed by early use of oral rehydration therapy and continuous feeding of undiluted milk formula, so the usage of lactose-free formula is not essential [19]. Our study showed that the weight increased in both groups, $p$ value more than 0.2 which is not significant. The same result found in Hossien Saniean research [16]. Our study showed $23.3 \%$ of patients discharged at the third post admission days in patient on lactose-free formula as they have more rapid recovery, $p<0.01$ significant. This result supported by research by BMJ group which showed patient on lactose-free milk have faster recovery (about 3 and half days) compared with patient on normal milk (about 5 days) [20]. Sadoon et al. study also support our results as $45.7 \%$ of patients on lactose-free formula discharged on the second-day postadmission while only $2 \%$ of patient on normal formula discharged on the second day [21].

\section{Conclusion}

Quick giving of lactose-free formulation to children on formula feeding show rapid relief of acute diarrhea.

\section{References}

1. Pathela P, Zahid Hasan K, Roy E, Huq F, Kasem Siddique A Bradley Sack R. Diarrheal illness in a cohort of children 0-2 years of age in rural Bangladesh: I. Incidence and risk factors. Acta Paediatr. 2006;95(4):430-7. https://doi. org/10.1080/08035250500444875

PMid: 16720490

2. Vila J, Oliveira I, Zboromyrska Y, Gascon J. Diarrea de viajero Traveller's diarrhoea. Enferm Infecc Microbiol Clin. 2016;34(9):579-84. https://doi.org/10.1016/j.eimc.2016.04.010

3. Applegate JA, Fischer Walker CL, Ambikapathi R, Black RE. Systematic review of probiotics for the treatment of communityacquired acute diarrhea in children. BMC Public Health. 2013;13(3):S16. https://doi.org/10.1186/1471-2458-13-s3-s16 PMid:24564646

4. Bhutta ZA, Das JK, Walker N, Rizvi A, Campbell H, Rudan I, et al, Lancet Diarrhoea and Pneumonia Interventions Study Group. Interventions to address deaths from childhood pneumonia and diarrhoea equitably: What works and at what cost? Lancet. 2013;381(9875):1417-29. https://doi.org/10.1016/ s0140-6736(13)60648-0

PMid:23582723

5. Bhutta ZA, Black RE, Chopra M, Morris SS. Excellent can be the enemy of good: The case of diarrhoea management-authors' reply. Lancet. 2013;382(9889):308. https://doi.org/10.1016/ s0140-6736(13)61634-7

PMid:23890042

6. Patro B, Szymanski H, Szajewska H. Oral zinc for the treatment of acute, gastroenteritis in Polish children: A randomized, doubleblind, placebocontrolled trial. J Pediatr. 2010;157(6):984-8. https://doi.org/10.1016/j.jpeds.2010.05.049

PMid:20619853

7. Osterholm MT. Foodborne disease in 2011-the rest of the story N Engl J Med. 2011;2364(10):889-91. https://doi.org/10.1056/ nejmp1010907

PMid:21345094

8. Richardson V, Hernandez-Pichardo J, Quintanar-Solares M, Esparza-Aguilar M, Johnson B, Gomez-Altamirano CM, et al. Effect of rotavirus vaccination on death from childhood diarrhea in Mexico. N Engl J Med. 2010;362:299-305. https://doi. org/10.1056/nejmoa0905211

9. Das JK, Ali A, Salam RA, Bhutta ZA. Antibiotics for the treatment of cholera, Shigella and Cryptosporidium in children. BMC Public Health. 2013;13(3):S10. https://doi. org/10.1186/1471-2458-13-s3-s10

PMid:24564492

10. Guarino A, Ashkenazi S, Gendrel D, Lo Vecchio A Shamir R, Szajewska H, European Society for Pediatric Gastroenterology, Hepatology, and Nutrition; European Society for Pediatric Infectious Diseases. European society for pediatric gastroenterology, hepatology, and nutrition/European society for pediatric infectious diseases evidence-based guidelines for the management of acute gastroenteritis in children in Europe: 
Update 2014. J Pediatr Gastroenterol Nutr. 2014;59(1):132-52. https://doi.org/10.1097/mpg.0000000000000375

PMid:24739189

11. Probiotics revisited. Med Lett Drugs Ther. 2012;55(1407):3-4.

12. Colletti JE, Brown KM, Sharieff GQ, Barata IA, Ishimine P, ACEP Pediatric Emergency Medicine Committee. The management of children with gastroenteritis and dehydration in the emergency department. J Emerg Med. 2010;38(5):686-98. https://doi. org/10.1016/j.jemermed.2008.06.015

PMid:19345549

13. Perino A, Cabras S, Obinu D, Cavalli Sforza L. Lactose intolerance: A non-allergic disorder often managed by allergologists. Eur Ann Allergy Clin Immunol. 2009;41(1):3-16. PMid:19496347

14. Hu Y, Gui L, Chang J, Liu J, Xu S, Deng C, et al. The incidence of infants with rotavirus enteritis combined with lactose intolerance. Pak J Pharm Sci. 2016;29(1):321-3.

PMid:27005498

15. Turck $D$. Prevention and treatment of acute diarrhea in infants Arch Pediatr. 2007;14(11):1375-8. https://doi.org/10.1016/j. arcped.2007.06.009

PMid:17629685
16. Saneian H, Yaghini O, Modaresi M, Razmkhah N. Lactosefree compared with lactose-containing formula in dietary management of acute childhood diarrhea. Iran J Pediatr. 2012;22(1):82-6

PMid:23056864

17. $\mathrm{Xu} \mathrm{JH}$, Huang $\mathrm{Y}$. Efficiency of lactose-free formula feeding as an adjunctive therapy in infants with acute diarrhea. Zhongguo Dang Dai Er Ke Za Zhi. 2009;11(7):532-6.

PMid:19650983

18. Le Luyer B, Makhoul G, Duhamel JF. A multicentric study of a lactose free formula supplemented with Saccharomyces boulardii in children with acute diarrhea. Arch Pediatr. 2010;17(5):459-65. https://doi.org/10.1016/j.arcped.2010.02.004 PMid:20236813

19. Gaffey MF, Wazny K, Bassani DG, Bhutta ZA. Dietary management of childhood diarrhea in low-and middleincome countries: A systematic review. BMC Public Health. 2013;13(3):S17. https://doi.org/10.1186/1471-2458-13-s3-s17 PMid:24564685

20. Dalby-Payne JR, Elliott EJ. Gastroenteritis in children. BMJ Clin Evid. 2009;2009:0314.

21. AL Sadoon ER, AL-Juboori LF, Ahmed MA. Role of lactose free milk in acute diarrhea. Tikrit J Pharm Sci. 2011;7(2):1-4. 